DOI https://doi.org/10.36059/978-966-397-226-8-3

\title{
MEANS OF THE FOREIGN LANGUAGE REMOTE TEACHING ORGANIZATION
}

\section{Kuzmenko A. O.}

\section{INTRODUCTION}

Currently, the process of society informatization has become one of the most significant global processes of our time. Informatization as an objective regularity is inevitable and is one of the conditions for the successful solution of the problems of socio-economic development and military construction in any country, and one of its priority areas is the informatization of education, which creates a material and methodological basis for the emergence and development of new forms of education ${ }^{65}$.

The success of modern education is determined, first of all, by a flexible response to constantly changing conditions. The state and society need a specialist who is able to restructure the content of his activities in accordance with the changing requirements of the labour market $^{66}$.

Remote teaching, which implies the transmission of knowledge over a distance, today has already acquired the status of a traditional form of education. At the present stage of education development, remote education presupposes skills in handling the latest information technologies, the ability to work with text and the availability of appropriate electronic support for all participants in the process academic staff and undergraduates.

The investigations of Yu. K. Babansky ${ }^{67}$, Z. R. Devterova ${ }^{68}$, E. S. Polat ${ }^{69}$, etc. are devoted to forms and means of teaching.

\footnotetext{
${ }^{65}$ Андреев, А. А. (1998). Введение в дистанционное обучение. Ч. ІІ. М. : МЭСИ. 17 с.

${ }^{66}$ Кашлач, В. М. (2010). Становление профессиональной мобильности педагога в процессе профессионального образования. Сибирский педагогический журнал. № 3. C. $28-33$.

${ }^{67}$ Бабанский, Ю. К. (1987). Интенсификация процесса обучения. М. : Знание. 80 с. ${ }^{68}$ Девтерова, 3. Р. (2010). Методология реализации систем дистанционного обучения. Сибирский педагогический журнал. № 11. С. 31-39.
} 
The essence of new information technologies in remote teaching has been considered by V. Yu. Bykov ${ }^{70}$, G. Davies ${ }^{71}$, T. Husak ${ }^{72}$ and others. The works of N. A. Kameneva ${ }^{73}$, I. V. Kiian ${ }^{74}$, R. E. Sadoyan ${ }^{75}$ and others deal with organization of a computer (programmed) teaching process.

The idea of foreign language remote teaching is that the interaction of the academic staff member and the undergraduate takes place in cyberspace. They are both at their computers and communicate mainly in a foreign language via the Internet. The world's telecommunications infrastructure today makes it possible to create systems of mass lifelong learning, general exchange of information, regardless of temporal and spatial zones. Remote teaching has entered the XXI century as the most effective system of training and continuous support of highly qualified specialists.

The organization of virtual spaces as a kind of entry points for undergraduates of a certain level ("classrooms"), where links lead to individual offices of an academic staff member, where there is a direct educational interaction. Models, forms and means of remote teaching can be selected for the educational process depending on the size of the group, the number of groups, other features of the educational process in the institution and taking into account the characteristics of the discipline studied and the specifics of the group (number of applicants, number of subgroups, etc.). These models, forms and means tend to be investigated in the following abstracts.

\footnotetext{
${ }^{69}$ Полат, Е. С. (2004). Теория и практика дистанционного обучения : учеб. пособие. М. : Академия. $416 \mathrm{c.}$

${ }^{70}$ Биков, В. Ю. (2001). Дистанційна освіта - перспективний шлях до розвитку професійної освіти. Педагогічна газета. № 1. С. 2.

${ }^{71}$ Davies G., Higgins J. (1982). Computers in Language and Language Learning. London: CILTR. 285 p.

${ }^{72}$ Гусак Т., Малінко О. (2000). Можливості та перспективи дистанційного навчання у вузі. Рідна школа. № 10. С. 41-42.

${ }_{73}^{73}$ Каменева, Н. А., Зенина, Л. В. (2013). Distance learning for developing knowledge and skills in English language teaching. Вестник УМО. № 5. С. 3-6.

${ }^{74}$ Киян, И. В. (2010). Варианты контроля знаний в системе дистанционного обучения. Сибирский педагогический журнал. № 12. С. 52-58.

${ }^{75}$ Садоян, Р. Э. (1998). Начальный этап построения системы мультимедийного дистанционного обучения иностранным языкам. Дистанционное образование. № 2. C. $26-31$.
} 


\section{E-service as a form of remote teaching platform}

The use of information computer technologies can significantly increase the cognitive and communicative interest of undergraduates in the study of a foreign language, the desire for independent work in mastering a foreign language and professional knowledge in the context of remote education, allows a better and more efficient differentiation of learning and helps and eliminates knowledge gaps, and expands own knowledge.

Internet technologies within the framework of this training make it possible to form the skills and abilities of reading, oral and written speech of undergraduates, thanks to the inexhaustible information resources of the global network: news information from around the world, encyclopedias, regional studies and other $\operatorname{sites}^{76}$. A significant contribution to the development of modern remote teaching technologies has been made by different software products, which can provide a constructive dialogue between an academic staff member and an undergraduate or a group of undergraduates. To provide remote teaching in the most productive way it is proposed different software products / e-services for organization remote teaching process.

Although, how perfect the platform is, an academic staff member starts with telephone calls or messaging for giving information about future work on a platform, instructions about the access, registration or links to join (Picture 1).

Social networks, remote messaging services and mobile applications such as Viber, Telegram, WhatsUp allow you to create closed groups, communities, chats, discuss topics, tasks, problems, information.

The Moodle platform (https://moodle.org/) is a free open remote teaching management system ${ }^{77}$. It allows using a wide range of tools for educational interaction between academic staff, undergraduates and the administration of the educational institution. In particular, it provides an opportunity to submit educational material in various formats (text, presentation, video, web page; lesson as a set of web pages with

\footnotetext{
${ }^{76}$ Гутарева, Н. Ю. Дистанционное обучение иностранным языкам в неязыковом вузе. URL: http://psibook.com/linguistics/distantsionnoeobuchenie-inostrannym-yazykam-vneyazykovom-vuze.html.

${ }^{77}$ Moodle. URL: https://moodle.org/?lang=ru.
} 
a possible intermediate performance of test tasks); to carry out testing and interrogation of undergraduates with the use of questions of the closed (multiple choice of the correct answer and comparison) and open types; undergraduates can complete tasks with the ability to send relevant files.
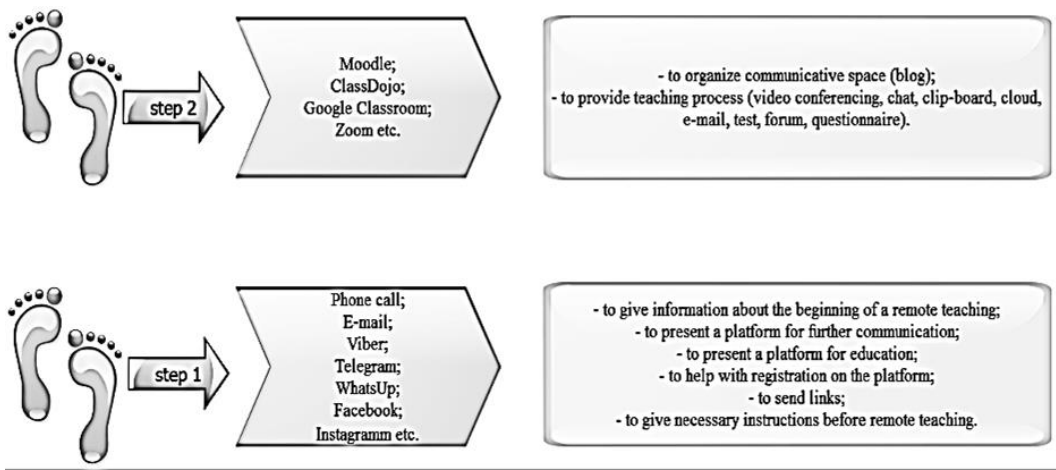

\section{Picture 1. On-line services for organization remote teaching process}

In addition, the system has a wide range of tools for monitoring undergraduates' learning activities, such as: the total time of the undergraduate's work with a particular subject, relevant topics or components of the material, the overall performance of the undergraduate or class in the test. Moodle has in its tools: forms of submission of tasks; discussion forums; download files; evaluation journal; messaging; calendar of events; news and announcements; online testing; Wiki resources.

ClassDojo $^{78}$ is a closed educational social network developed by British teachers and IT technologists, which has a high degree of personal data protection. The ClassDojo remote teaching platform is one of the most convenient. It is suitable for desktop PCs, laptops, tablets and mobile phones. The principle of work is simple and convenient: an academic staff member registers on the platform, creates his/her

\footnotetext{
${ }^{78}$ ClassDojo. URL: https://www.classdojo.com.
} 
"Class", adds undergraduates and sends them links to the "Class". Communication between an academic staff member and undergraduates will take place as follows: Class participants will see publications from the academic staff member in chronological order. It is a bit like the usual news feed on social media. The academic staff member will be able to attach to the materials and tasks PDF-files, links to web resources. A separate option of the platform is to create tasks of four types. An undergraduate can write a work and attach a file or draw a work, take a photo or make a short video. The academic staff member can immediately see what task an undergraduate has completed. A big plus is the opportunity for undergraduates to communicate on the "Class" page: after the academic staff member has created a post, undergraduates can comment on it. The academic staff member can explain something to them there.

The bonus will be the gamification of learning. Each undergraduate will receive an avatar in the form of a monster. The task of the monster is to collect points for the task. It is assigned a certain number of points to the undergraduate for each academic staff member. It is advised to develop an interesting economic marathon for the time of remote work: to announce that in a month each monster should gather 300 "creatives" (name the currency in points as you like). As soon as an academic staff member assigns points, a student receives a green circle and “+10", “+5" on the avatar. For non-fulfillment of deadlines and tasks, an academic staff member, on the contrary, can remove the "creative" from the student - then a red circle with the inscriptions " -10 ", " -15 " will light around his/her avatar. So, the monster will have to perform some other tasks to cover the negative balance.

Another big plus is that parents can join this system by invitation via the link. They have to download the application to the phone and enter the code from an academic staff member. Again, an academic staff member send links to parents so that they can see only their child and their results in the Classroom, as well as a taskbar and comments from everyone. This is how parents will be able to track the child's progress during remote teaching in the dynamics. 
Google Classroom ${ }^{79}$ is a free service that anyone with a Google Account can use. An academic staff member enters the system and creates his / her "Class", where he / she will publish teaching materials, give tasks to undergraduates and communicate with them. Links to this "Class" should be sent to all undergraduates. If undergraduates use the platform from the phone, they must download the application of the same name to the mobile.

Thus, an academic staff member will arrange the lessons in the "Classroom" in a clear sequence, and undergraduates will be able to comment on these lessons and see all the necessary references and their grades. All this is on one page.

The Google Classroom platform is a service that connects Google Docs, Google Drive and Gmail, allowing an academic staff member to organize online teaching using video, text and graphics. A academic staff member has an opportunity to test, monitor, systematize, evaluate activities, review the results of exercises, apply various forms of assessment, comment and organize effective communication with undergraduates in real time. The main element of Google Classroom is groups. Functionally, groups resemble the structure of forums, as they allow users to send messages to other users easily. With the Hangouts service, undergraduates and academic staff can have real-time online conversations using a computer or a mobile device, and team members can show their screens, watch, and work together. This broadcast will automatically post to the YouTube channel. The platform also allows Google forms to collect undergraduate's responses and then automatically evaluate test results.

Zoom $^{80}$ (zoom.us/download) is a service for video conferencing and online meetings. To do this, an academic staff member needs to create an account. The free version of the programme allows holding a video conference lasting 40 minutes, but for the period of the pandemic, the service removed this restriction. Zoom is suitable for individual and group classes. Users can use the application on a computer as well as on a tablet or smartphone. Any user can join the video conference by

\footnotetext{
${ }^{79}$ Google Classroom. URL: https://classroom.google.com.

${ }^{80}$ Zoom. URL: https://zoom.us.
} 
following the link or conference ID. Classes can be scheduled in advance, as well as links for regular meetings at a specific time. The platform has a built-in interactive whiteboard that can be shown to undergraduates. In addition, it can be easily and quickly switched from screen demonstration to interactive whiteboard.

\section{Arranging the foreign language remote teaching}

According to the use of media services, there are organizational and technological models of remote teaching: single media, multimedia, hypermedia and virtual university ${ }^{81}$.

Single media is the use of one mean of teaching and information transmission channel. For example, teaching through correspondence, educational radio or television programmes. The dominant learning tool is usually a printed material. There is almost no two-way communication, which brings this model of remote teaching closer to traditional part-time learning.

As for the English training, this type of media is good only for presenting theoretical material, lectures or teaching in form of 'peeping through a key hole' - broadcasting of a real life / offline lesson. This way an undergraduate is a recipient, but not a reproductive foreign language user.

Multimedia is the use of various teaching aids: printed materials, computer programmes for educational purposes on various media, audio and video recordings. However, the "one-direction" transfer of information dominates. If it is necessary, elements of full-time education such as meetings of undergraduates and an academic staff member, conducting final training seminars or consultations, face-to-face exams etc.

Hypermedia is a third-generation remote teaching model that involves the use of new information technologies with the dominant role of computer telecommunication systems. The simplest form is the use of e-mail and teleconferencing, as well as audio training (telephone). With further development, this model of remote teaching includes the use of a set of tools such as video, fax and telephone (for video conferencing)

\footnotetext{
${ }^{81}$ Ефремов, О. В., Беляев, П. С. Информационные системы в науке, образовании и бизнесе. URL: http://window.edu.ru/catalog/pdf2txt/601/38601/16379?p_page=5.
} 
and audiography with the simultaneous widespread use of video discs, various hyper tools, knowledge systems and artificial intelligence.

These types of media are transitional. They are rather convenient for teaching foreign languages and have a lot of advantages such as teaching listening skills with audio, linguocultural comprehension with video, speaking with audio training and e-mails.

Virtual universities. The training servers developed by universities are 'an extension of the walls' of the university itself. In its virtual classrooms, as well as in the main ones, it will be possible to listen to a lecture later, to perform a laboratory research on a virtual stand, and to find means for designing, performing calculations, modelling of the designed device. However, it is possible that all of the above will be the prerogative of specialized virtual universities - electronic open universities without walls.

This model is full of possibilities for teaching foreign languages with taking into account all the problems with the Internet services, personal priorities of an undergraduate. An undergraduate can decide when, how long and where to study, has an opportunity to revise the material and learn it as many times as it is needed. Furthermore, an academic staff member is able to watch the success of each student and to reorganize each lesson in a short time if the material is easy or difficult.

Thus, with realizing all the difficulties of teaching, learning and practicing foreign languages it is obvious that single media model is not appropriate as it does not provide duo-directed communication. It can be useful only for a traditional lecture (presenting grammar rules, explanation of lexical material or sound-pronunciation), but observation of undergraduates' success in learning is impossible.

More useful remote classes are possible with multimedia model, however, the best models, which provide the realization of all types of activities in the foreign language classes, are hypermedia and virtual university.

These models ensure success by highly-developed bifurcation in choosing types of a lesson based on communication opportunity. To make it more available within the capacity and needs of foreign language teaching there are some tasks to be solved. The main tasks solved by communication systems are the creation of a communicative space and 
of educational process organization. Each of these tasks has its purposes with the ways to achieve them (Picture 2).

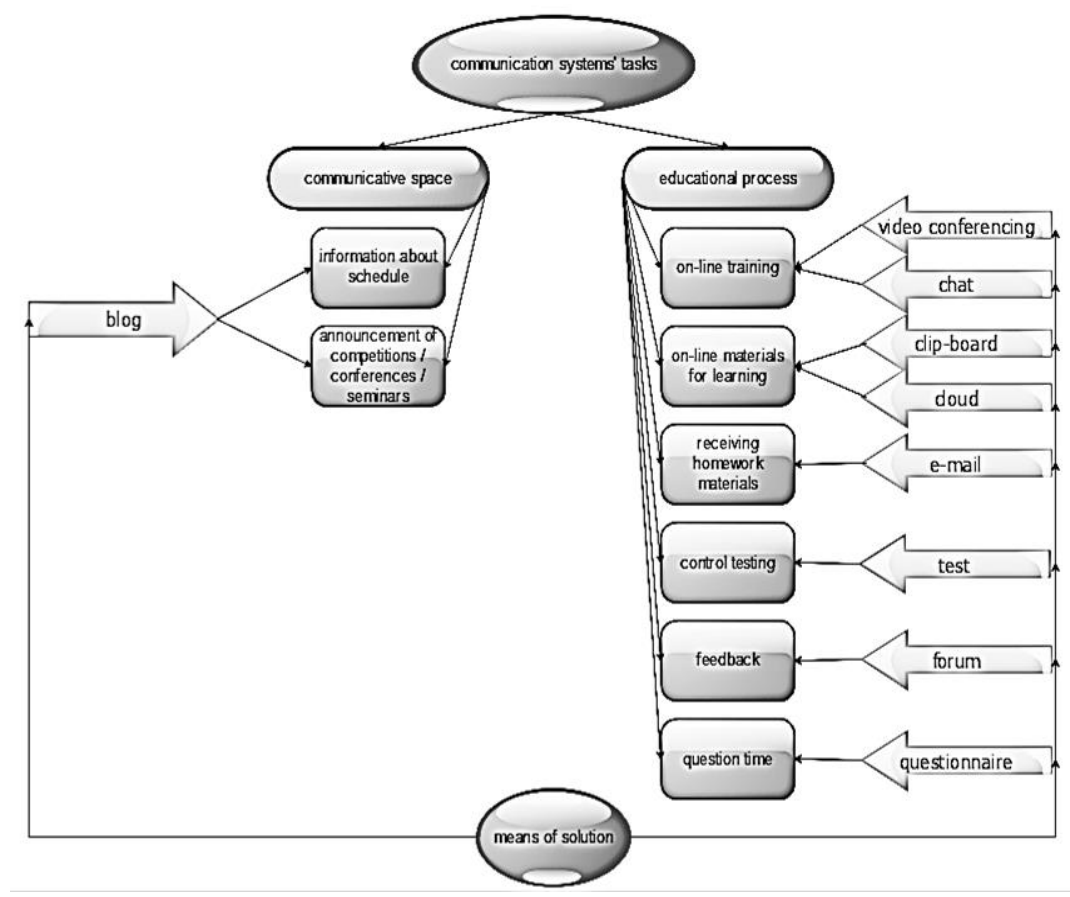

Picture 2. Communication systems' tasks and means of their solution

Creating a communicative space. It means the establishment of primary communication between undergraduates and an academic staff member. Such communication includes:

- information about schedule. An academic staff member can provide the information about the timetable of the following lesson, its delay or cancellation.

Also, undergraduates can be informed about the presence of other people in the lesson, e.g. a native speaker, an administration member, a student-assistant and so on;

- announcement of competitions / conferences / seminars. An academic staff member can propose the participation in different educational and scientific events to demonstrate undergraduate's 
knowledge, compete with undergraduates of other educational institutions sharing their ideas in a foreign language. Sometimes such events are visited by citizens of foreign countries. This usually encourages undergraduates to learn a foreign language harder.

Both of these communication aims can be reached with a blog. A blog is a form of communication, where the right to publish belongs to one person or group of people. The author (mainly an academic staff member) posts a message / note on the website of his / her blog and gives the opportunity to undergraduates to read and comment on the posted material. Students have the opportunity to discuss and evaluate the quality of the publication, including in a foreign language, which promotes the development of speech skills.

These tasks are best done through remote messaging services, social networks (closed groups or communities). For such purposes, it is also possible to use the site of the educational institution (for messages that may be public, and for all messages, if the site has limited access only for higher education).

Educational process organization. It should provide the following functions:

- conducting on-line classes. Teaching a foreign language is impossible without life communication of speakers. For instance, only in such a way it is possible to check the correctness of pronunciation, undergraduate's speed of speech etc.

To conduct a successful synchronous on-line class it is better to use video conferencing. Video conferencing is a real-time online conference. It is held on a specific day and time. Video conferencing is one of the modern ways of communication, which allows you to conduct classes in "remote classes" when undergraduates and an academic staff member are at a distance. Thus, discussions and decisions, defense of projects take place in real time. An academic staff member and undergraduates can see each other, an academic staff member has the opportunity to accompany the lecture with visual material. This way, it is possible to provide classes similar to full-time face-to-face classes. An academic staff member has an opportunity to provide more oral activities such as reading aloud, monologues, dialogues, polylogue discussions etc. Video conferencing helps to follow the immediate foreign-language speech 
reaction of each undergraduate, to receive undergraduate's work and check his / her mistakes simultaneously, to understand the level and the speed of undergraduates' foreign-language comprehension skills.

One of the most productive forms of video conferencing is webinar (web-based seminar). Web-based seminar was first used in 1998 and now it is one of the most popular and effective forms of distance teaching today ${ }^{82}$. The main feature of webinars is their interactivity, the ability of participants to demonstrate, give, receive and discuss information. Unlike the technology of using webcasts, in which data is transmitted only in one direction, the interaction of the lecturer with the audience is possible at webinars.

A characteristic feature of webinars is the use of special web technologies and the indispensable communication in synchronous live broadcast mode. As a rule, webinars on teaching a foreign language provide the opportunity: multilateral video and audio communication, downloading and watching presentations and videos, text chat, polling, demonstrating the academic staff member's computer screen to undergraduates, as well as transferring control rights from the academic staff member to undergraduates ${ }^{83}$

When using this form of teaching a foreign language, the undoubted advantage is the flexibility of the learning process, because to the greatest extent, the undergraduates' capabilities, the level of their knowledge are taken into account, it becomes possible to determine an individual approach to teaching, methods, time and duration of studying the material. The flexibility of training is due to a large extent to the fact that webinars are consideration of small blocks (modules), and training materials are updated in a timely and efficient manner.

Webinars are interactive; an undergraduate is involved in active cognitive communicative activity, involving the use of language knowledge to solve communication problems joining creative activities

\footnotetext{
${ }^{82}$ Воронова, Е. Н. (2015). Критерии оценки и самооценки выполнения Веб-квеста по иностранному языку студентами вуза. Web-технологии в образовательном пространстве: проблемы, подходы, перспективы. Сборник статей участников Международной научно-практической конференции. Н. Новгород, Арзамас : ООО «Растр-НН». $581 \mathrm{c.}$

${ }^{83}$ Шалимова, Г. В. (2010) Вебинар или семинар? URL: https://conf.sfedu.ru/inftech2010/BR/ Shaliova.pdf. C. 65 .
} 
in groups. However, it should be noted that the emotional connection between participants in the webinar is rather weak compared to live communication, which may somewhat reduce the effectiveness of training in certain aspects. Another inconvenience of the considered form of training is a variety of technical malfunctions that can significantly change the course of the planned webinar or even cause the session to be canceled at the appointed time.

Conducting a webinar while teaching a foreign language requires not only a careful selection of material that should be most effectively perceived by participants to assimilate specific thematic information in the context of on-line training, but also the development of several scenarios for the webinar, which in case of unforeseen situations will help to promptly respond to them and continue training. When teaching foreign languages, the disadvantage of a webinar can be the loss of contact between the academic staff member and the audience due to the fact that the academic staff member does not always see the reactions of the webinar listeners, as well as the loss of the rhythm of the lesson for the same reason.

To conduct an on-line post-class educational-entertaining activity it is important to use chat. Chat is network users' communication in real time, a means of operational communication of people via the Internet. There are several types of chats: text, voice, audio, video chat. The most common is text chat. Voice chat allows you to communicate by voice, which is an important point when learning a foreign language remotely. For educational purposes, if necessary, you can organize communication in chats with native speakers. This is a real opportunity for language practice, which is carried out in the framework of the proposed problem for discussion, join project activities, information exchange;

- access to various electronic educational materials. An academic staff member should provide all the necessary materials (plan of the educational process, textbooks, students' books, workbooks, web-sites etc.) for education using their on-line versions.

Clip-boards or e-clouds are the most popular services which help to store different resources of various sizes for a long time and make it possible to access anywhen; 
- obtaining undergraduates' homework materials. An academic staff member needs to receive all the homework materials to get acquainted with undergraduates' works before their assessment. Such homework materials may be performed in

1) a handwriting form to check undergraduates' work in details because some skills are shown only in handwriting. For example, spelling skills - computer programmes sometimes correct such people's mistakes. Thus, when an undergraduate writes a composition in the copybook, then takes photos and sends them to an academic staff member it is possible to notice different elementary problems;

2) a computer form such as a slide-show project and so on. It helps to analyze general competence of an undergraduate: to understand his / her level of lingvo-cultural, communicative and creative skills.

To receive undergraduates' homework materials e-mail is widely used. E-mail is a standard Internet service that provides the transmission of messages in the form of a text and in other forms (graphic, audio, video) in open or encrypted form;

- control testing. Control testing provides objective assessment of an undergraduate's knowledge and skills. The platform will count the number of correct answers and convert them into marks. Unfortunately, for such objectivity it is mostly possible to create just a multiple choice task for checking grammar, vocabulary, listening and writing activity. However, it is rather difficult to check speaking and pronunciation. An academic staff member can realize just comprehension in such exercises as "Find out the necessary transcription to the word" or "Find the correct answer to the question", but it does not mean that an undergraduate is able to pronounce the transcription correctly or to answer the question him/herself;

- feedback. Any lesson's feedback may be done duo-directed. It means that an academic staff member can write a short note with recommendations or praise to each undergraduate, paying attention to his / her strong and weak points and ways to prevent mistakes in future, give marks for performed tasks. Moreover, an undergraduate can express his / her attitude to the lesson and each task separately, giving his / her arguments and justifications. 
To provide a feedback to the lesson an academic staff members prefer to use forums. Forum is the most common form of communication between an academic staff member and undergraduates in remote teaching. Each forum is dedicated to a specific problem or topic. The moderator of the forum implements discussions, stimulating questions, messages, new interesting information. Forum software allows you to attach various files of a certain size. You can combine several forums into one big one;

- question time. It means that both an academic staff member and an undergraduate have the opportunity to ask questions and get an answer outside the on-line lesson. It is a common thing that some undergraduates are shy and they do not ask to explain difficult material once again during the lesson. They are afraid to be laughed at or bulled by others. Questionnaire makes it possible to communicate with an academic staff member and to share any problems without the presence of other undergraduates. Furthermore, an academic staff member may notice that an undergraduate has a bad mood or a puzzled look, bad understanding or copying works instead of doing him-/herself. In such cases an academic staff member should make questions to this undergraduate in a private form and discuss all the problems and difficulties.

Questionnaire is used for the current control during remote teaching. It is convenient to use a variety of questionnaires. The questionnaire is a fairly flexible tool, as questions can be asked in many different ways. In remote teaching, after mastering each topic, you can use questionnaires in which the student can make a self-assessment of learning outcomes on the following indicators: understand / understand, I can solve the task on my own; understand / understand, I can solve with a hint; misunderstand / do not understand at all, I can not solve the task on my own.

\section{CONCLUSIONS}

To conclude, remote teaching is a traditional form of education nowadays. Its implementation needs some academic staff's and undergraduates' skills in handling up-to-date information technologies, the capacity to work with text and the availability of appropriate electronic support. 
There are various e-platforms for providing excellent classes and after-classes activities. The most effective ones are Moodle, ClassDojo, GoogleClassroom, Zoom. Moodle is a free open remote teaching management system, which provides an opportunity to submit educational material in various formats; to carry out testing and interrogation of undergraduates with the use of questions of the closed and open types; undergraduates can complete tasks with the ability to send relevant files. ClassDojo is a closed educational social network, where its participants can write a work and attach a file or draw a work, take a photo or make a short video. Google Classroom is a free service for organizing online teaching using video, text and graphics. Zoom is a service for video conferencing and online meetings.

According to the use of media services, there are organizational and technological models of remote teaching: single media, multimedia, hypermedia and virtual university.

Before starting each of these models, an academic staff member should do two steps. Step one is to give information about the beginning of a remote teaching; to present a platform for further communication; to present a platform for education; to help with registration on the platform; to send links; to give necessary instructions before remote teaching. It can be used such on-line forms for these purposes as Phone call; E-mail; Viber; Telegram; WhatsUp; Facebook; Instagramm etc. Step two is to organize communicative space; to provide teaching process. Creating a communicative space means the establishment of primary communication between undergraduates and an academic staff member: information about schedule, announcement of competitions / conferences / seminars. All these can be done with a blog. Educational process organization should provide such functions as conducting on-line classes, access to various electronic educational materials, obtaining undergraduates' homework materials, control testing, feedback and question time. Such tasks are solved with video conferencing (webinar), chat, clip-board, cloud, e-mail, test, forum or questionnaire. For all these purposes it can be used Moodle; ClassDojo; Google Classroom; Zoom etc. 


\section{SUMMARY}

The article deals with the peculiarities of implementation remote teaching form of education in the English language classes. Remote education presupposes skills in handling up-to-date information technologies, the capacity to work with text and the availability of appropriate electronic support for academic staff and undergraduates. The problem of remote teaching has been interested for a lot of scientists such as V. Yu. Bykov, G. Davies, T. Husak, N. A. Kameneva, I. V. Kiian, R. E. Sadoyan and others.

A significant contribution to the development of modern remote teaching technologies has been made by e-services. Moodle is a free open remote teaching management system, which provides an opportunity to submit educational material in various formats (text, presentation, video, web page; lesson as a set of web pages with a possible intermediate performance of test tasks); to carry out testing and interrogation of undergraduates with the use of questions of the closed (multiple choice of the correct answer and comparison) and open types; undergraduates can complete tasks with the ability to send relevant files. ClassDojo is a closed educational social network, where its participants can write a work and attach a file or draw a work, take a photo or make a short video. Google Classroom is a free service for organizing online teaching using video, text and graphics. Zoom is a service for video conferencing and online meetings.

According to the use of media services, there are organizational and technological models of remote teaching: single media, multimedia, hypermedia and virtual university, which need the communication system organization.

The main tasks solved by communication systems are the creation of a communicative space and of educational process organization. Creating a communicative space means the establishment of primary communication between undergraduates and an academic staff member: information about schedule, announcement of competitions / conferences / seminars. All these can be done with a blog. Educational process organization should provide such functions as conducting on-line classes, access to various electronic educational materials, obtaining undergraduates' homework materials, control testing, feedback and 
question time. Such tasks are solved with video conferencing (webinar), chat, clip-board, cloud, e-mail, test, forum or questionnaire.

\section{REFERENCES}

1. Андреев, А. А. (1998). Введение в дистанционное обучение. Ч. ІІ. М.: МЭСИ. 150 с.

2. Бабанский, Ю. К. (1987). Интенсификация процесса обучения. М.: Знание. $80 \mathrm{c.}$

3. Биков, В. Ю. (2001). Дистанційна освіта - перспективний шлях до розвитку професійної освіти. Педагогічна газета. № 1. С. 2.

4. Воронова, Е. Н. (2015). Критерии оценки и самооценки выполнения Веб-квеста по иностранному языку студентами вуза. Web-технологии вобразовательном пространстве: проблемы, подходы, перспективы. Сборник статей участников Международной научно-практической конференции. Н. Новгород, Арзамас : ООО «Растр-НН». 581 с.

5. Гусак, Т., Малінко, О. (2000). Можливості та перспективи дистанційного навчання у вузі. Рідна школа. № 10. С. 41-42.

6. Гутарева Н. Ю. Дистанционное обучение иностранным языкам в неязыковом вузе. URL: http://psibook.com/linguistics/ distantsionnoeobuchenie-inostrannym-yazykam-v-neyazykovom-vuze.html.

7. Девтерова, 3. Р. (2010). Методология реализации систем дистанционного обучения. Сибирский педагогический журнал. № 11. C. 31-39.

8. Каменева, Н. А., Зенина, Л. В. (2013). Distance learning for developing knowledge and skills in English language teaching. Вестник УМO. № 5. С. 3-6.

9. Кашлач, В. М. (2010). Становление профессиональной мобильности педагога в процессе профессионального образования. Сибирский педагогический журнал. № 3. С. 28-33.

10. Киян, И. В. (2010). Варианты контроля знаний в системе дистанционного обучения. Сибирский педагогический журнал. № 12. C. 52-58.

11. Полат, Е. С. (2004). Теория и практика дистанционного обучения : учеб. пособие. М. : Академия. 416 с.

12. Садоян, Р.Э. (1998). Начальный этап построения системы мультимедийного дистанционного обучения иностранным языкам. Дистанциионое образование. № 2. С. 26-31. 
13. Шалимова, Г. В. (2010). Вебинар или семинар? URL: https://conf.sfedu.ru/inftech2010/ BR/Shaliova.pdf. C. 65.

14. Davies G., Higgins J. (1982). Computers in Language and Language Learning. London : CILTR. 285 p.

15. ClassDojo. URL: https://www.classdojo.com.

16. Google Classroom. URL: https://classroom.google.com.

17. Moodle. URL: https://moodle.org/?lang=ru.

18. Zoom. URL: https://zoom.us. 